Journal of Engineering and Applied Sciences 14 (Special Issue 5): 8991-8996, 2019

ISSN: $1816-949 \mathrm{X}$

(C) Medwell Journals, 2019

\title{
Field Measurement the Radioactivity of Liberated Regions (Samarra-Himreen Hills and Mosul) in Iraq after ISIS Occupation
}

\author{
${ }^{1}$ Sfeer AbdulKareem Alsaati, ${ }^{1}$ Mohammed Hadi Shinen, ${ }^{2}$ Hussain Ali Laken, \\ ${ }^{1}$ Amjed Mirza Oda, ${ }^{1}$ Abbas Hussain Mughear and ${ }^{1}$ Foad Zuhair \\ ${ }^{1}$ Department of Science, Basic Education College, University of Babylon, Iraq \\ ${ }^{2}$ Directorate General of the Education of Babylon, Ministry of Education, Iraq
}

\begin{abstract}
The damages come from exposing to radioactive radiation are severely huge and the injury diagnosis known after suffering from dose of one of radioactive elements. Thus field detection of radioactivity is very necessary to ensure the civilians regions are without radioactive pollution that results from natural disaster or human's wars. In this study, the researchers are trying to measure the radioactivite pollution in Iraq through the war against "Iraq and Sham Islamic State" ISIS (The Non-Islamic) because these land are controlled by ISIS and they used bombs and explosives that might be polluted or have additives of radioactive element. The location of this study is between Samarra governorate through cities that leading to Allas oil fields in the length line $\left(51^{\circ} 43^{\prime} 17^{\prime \prime}\right)$ and width line $\left(11^{\circ} 34^{\prime} 15^{\prime \prime}\right)$ to $\left(59^{\circ} 43^{\prime} 47^{\prime \prime}\right)$ and $\left(57^{\circ} 34^{\prime} 23^{\prime \prime}\right)$, after measuring along this road we found the radioactivity is in the range $0.438-1.1388 \mu \mathrm{Sev} / \mathrm{year}$ and these values are within the permitted dose as reported by World Health Organization (WHO) which is equal to $3 \mathrm{mSev} / \mathrm{year}$. The second area under study was the road of Samara to Mosel governorate reaching Tal Afar city at the Syrian borderlines in the length line $50^{\circ} 34^{\prime} 52^{\prime \prime}-26^{\circ} 42^{\prime} 37^{\prime \prime}$ and width line $11^{\circ} 34^{\prime} 46^{\prime \prime}-22^{\circ} 36^{\prime} 27^{\prime \prime}$ and the dose range was $0.516-1.883 \mu \mathrm{Sev} / \mathrm{year}$. These result are field measured, indicate that there is no possibility of radioactive pollution in the liberated regions in Iraq through the war against ISIS.
\end{abstract}

Keywords: Radioactivity, samarra, ISIS, Allas oil fields, Tal afer city

\section{INTRODUCTION}

The story of radiation begins with the first studies of radiation activity, represented by discovering of X-ray by Röntgen when it was produced in a vaccum tube in 1885. In 1896, Henry Becquerel discovered the radiation activity of certain substances when working on fluorescence salts. In 1898, Marie Curie discovered the external phenomena related to the interaction of radiation with materials and how to ionize them and focused on the polonium and radium elements. In the same year, the world discovered Thorium element that had the ability to ionize the material, which is similar to Uranium in physical properties (UNSCEAR., 1996).

In 1899, Rutherford classifies the ability of radioactive materials to penetrate and ionize. Some radioactive particles (alpha particles) can be stopped by placing a paper or a few centimeters away. In 1990, the world discovered the Radon, also Rhodes and Rutherford identified the generation of radon from the Radium element in the decay of the uranium and Thorium series. In the same year, the world discovered Gama rays which has high penetration due to its high energy and ability of ionization. Gama rays are classified as short-wavelength electromagnetic radiation (shorter than the wavelength of $\mathrm{X}$-rays) and most radioactive elements are emitting alpha or beta particles, or both. In 1903, the scientists Sudi and Rams discovered the radiation activity of gases escaped from Radium-containing compounds, then called Radon, which was considered an important element in the study of ionizing radiation, especially after World War II (Reed, 2014).

Radiation activity is an auto-decomposition of unstable nuclei to be more stable, accompanied by the emission of nuclear particles or electromagnetic radiation. Radioactive materials decay naturally by emitting nuclear particles into the external environment or ionizing radiation, or may come from space in as cosmic rays falling on the ground. Human activities, such as medical $\mathrm{x}$-ray, nuclear power generation, Nuclear weapons and the production of gases detectors containing radioactive materials, which lead to additional exposure to ionizing radiation. They can be classified as man-made radiation sources. The average annual exposure to radiation in the United States of America, which was contributed by all the main sources of radiation, as it is about $82 \%$ of the sources of this radiation from nature and $18 \%$ from the industrial, medical and consumer sources of human. In Table 1, the average values of radioactivity dose that exposed for the US people and vary depending on where people live (Links, 2006). 
J. Eng. Applied Sci., 14 (Special Issue 5): 8991-8996, 2019

Table 1: Annual radioactivity doses values in US

\begin{tabular}{lcc}
\hline Sources & $\begin{array}{c}\text { Dose } \\
\text { (mrem/year) }\end{array}$ & $\begin{array}{c}\text { Present of total } \\
(\%)\end{array}$ \\
\hline Natural radiation & & \\
Radon & 200.0 & 55.0 \\
Cosmic & 27.0 & 8.0 \\
Terrestrial (rock and soil) & 28.0 & 8.0 \\
Internal (inside human body) & 40.0 & 11.0 \\
Total natural & 295.0 & 82.0 \\
Man-made radiation & & \\
Medical X-Ray & 39.0 & 11.0 \\
Nutural medicine & 14.0 & 4.0 \\
Consumer products & 10.0 & 3.0 \\
Other & & \\
Occupational & 0.9 & $<0.3$ \\
Nuclear fuel cycle & $<1.0$ & $<0.3$ \\
Fallout & $<1.0$ & $<0.3$ \\
Miscellaneous & $<1.0$ & $<0.3$ \\
Total artificial & 65.0 & 18.0 \\
Total & 360.0 & 100.0 \\
\hline
\end{tabular}

The primary cosmic radiation consists of very high energy particles (up to 1018 volts), mostly protons ( $85 \%$ ), with some larger particles ( $14 \%$ alpha radiation), particles with a different charge (1\%). It comes from outside our solar system and it is found throughout the space. Some basic cosmic radiation is from the sun's rays, which are produced during interactions between the components of the sun or as far away as the solar system, even outside the Milky Way. Some initial cosmic radiation penetrates the Earth's surface (Grasty and LaMarre, 2004). The most cosmic rays interact with the atmosphere. These interactions produce other, less energy-intensive radiations in the form of photons, electrons, neutrons and muons that are present on the surface, leading to interaction with the Earth's atmosphere. When these radiation energy losses pass through the Earth's atmosphere, other secondary particles or new radionuclides in the air reach the Earth's surface and new radioactive nuclei such as tritium-3, pyrellium-7, carbon-14 and sodium-22 (Wahl, 2010).

Earth-based radiation is called Earth Radiation when the earth was formed seven billion years ago and contains many natural elements, some radioactive and non-radioactive, depending on the half-life of that element. These element are depleted from nature because the short half-life, but long some still exist so far and can be detected such as the potassium- 40 series, Uranium- 238 series and thorium-232 series. The dose derived from earth sources varies in different parts of the world according to their locations on the ground at different concentrations, where 67 radioactive sites identified by the competent authorities (UNSCEAR., 1996).

Any type of radioactive nucleus (terrestrial or cosmic) if entered into the body in any form such as air by inhalation, drinking water or eating, some radionuclides rapidly degrade and other radionuclides very slowly dissolve in body tissues (such as radium in the bones) can be damage the tissues and cause severe illness (Wahl, 2010).
The uranium series is one of the main radiation series in nature and is characterized by its length and abundance in the soil. It is the mother element of many elements. The following diagram shows how the nucleus of the uranium is decayed and the type of radiation generated by its transformation from one element to another. There is different life time reaching billions years like the conversion of uranium-238 to thorium-234, but some element may last for a few seconds as in the conversion of polonium-214 to Lead element-210 (Lehto and Hou, 2011; Field, 1999):

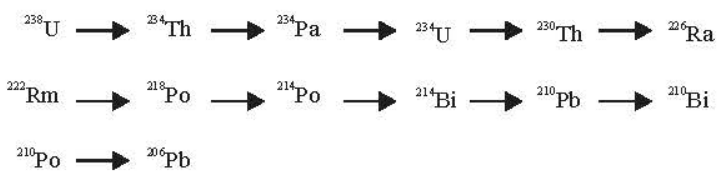

Uranium 235 is the only fissionable by neutrons and power generation. Uranium 238 is non-fissionable but when absorbed neutrons it becomes a fissionable plutonium. The plutonium 239 is not found in nature but is an industrial element. Natural and Depleted Uranium (DU) moves in the dust in the atmosphere to the earth, plants, surface water and groundwater to distant places and part of it is deposited in the ground or enters the roots of plants. This means that living organisms are surrounded by uranium because they may enter the air they breathe or in the water that Drink them or in the foods, especially those that grow inside the earth like potatoes, carrots and turnips. The nature of countries varies in their exposure to radiation depending on their geographical location on the earth and the nature of their land and water. In other words, human exposure to radiation is at varying rates. People living in nuclear power stations, close to nuclear weapons sites or close to Uranium enrichment sites have a high radiation exposure. The amount of Uranium that enters the body through breathing or eating is not absorbed and excreted from the body through waste, while the absorbed part of the radiation stabilizes in the body rate varies from one organ to another. The highest proportion of radiation is in the liver and kidneys and Uranium remains in bones about 70-200 days (ATSDR., 2013).

Iraq country suffering from two devastating wars in 1991 and 2003, during these war had been used a new weapons and sophisticated manufactured nuclear weapons in massive amount among them Depleted Uranium (DU) (Al-Ansari et al., 2014).

During Gulf War II in 1991, radionuclide contamination occurred in the Gulf War, where depleted uranium was used as penetrating ordnance causing contamination of the countryside of Iraq and the civilian population and military personnel exposed to DU dust, vapors and aerosols. U.S. and British troops in the second Gulf war in 2003 have used DU bombs and shells more 


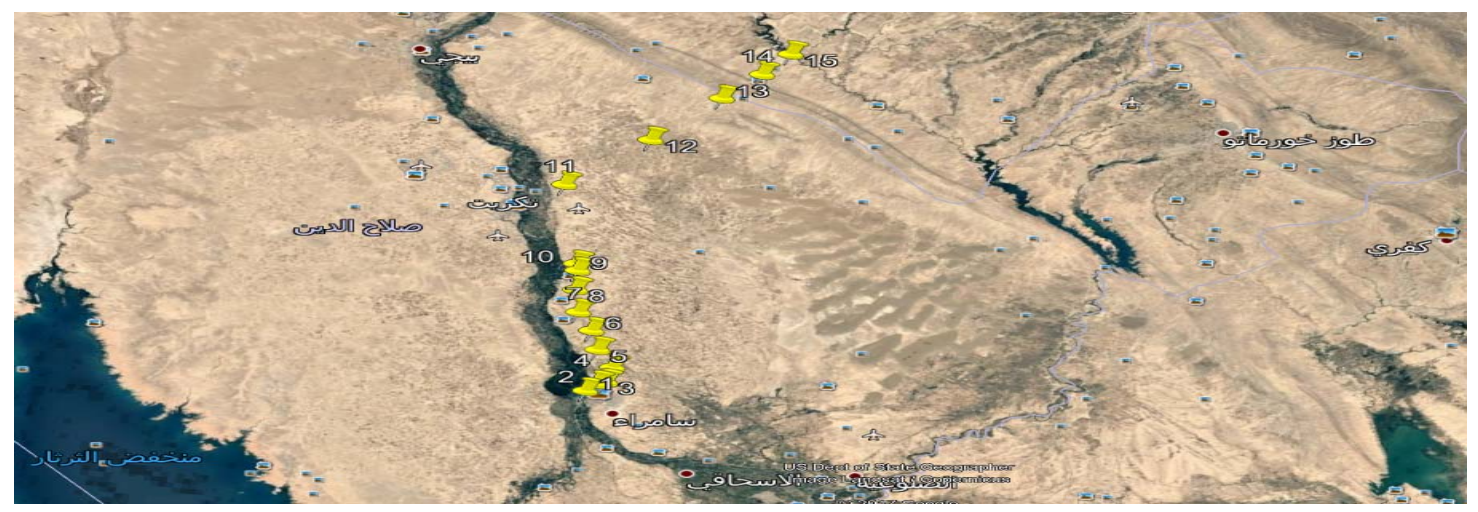

Fig. 1: Satellite map of the area under study (Samara to Himreen Hills)

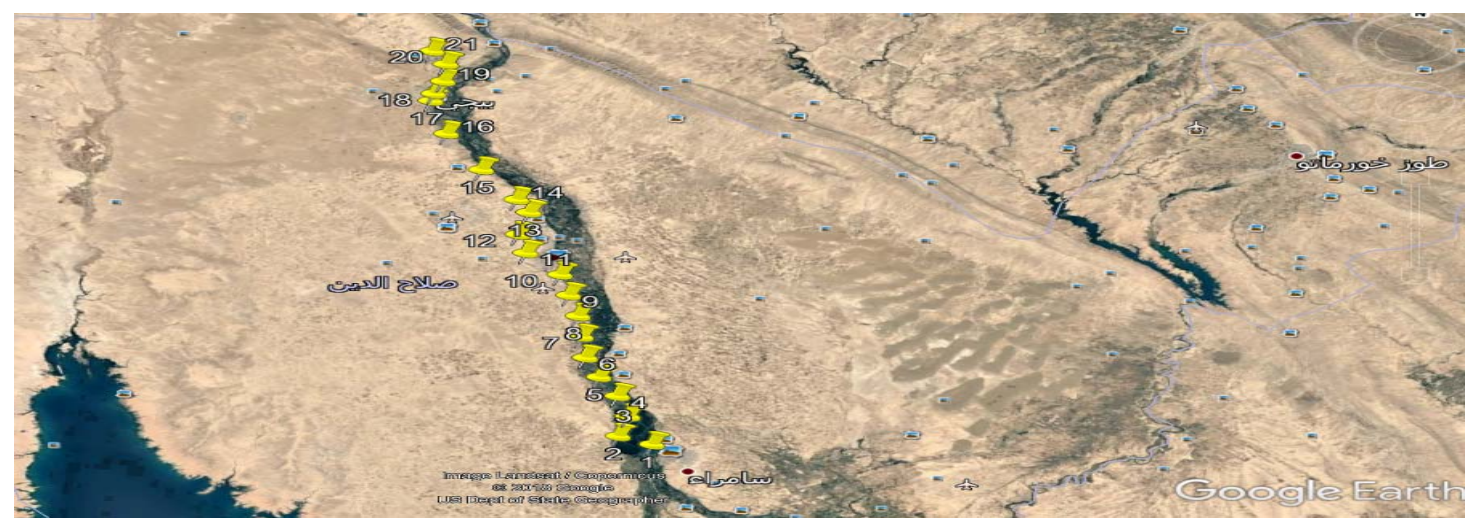

Fig. 2: Satellite map of the second area under study (Samara to Mosel)

than 5 times as many as the total number used during the 1991 war for the invasion of Iraq and about 1100-2200 $t$ of DU was used as estimated (Zwijnenburg, 2013).

In 2003, WHO was planning to put highlighting areas required involvement and demand support and funding due to DU contamination. this implemented was not applied due to lack of funding (WHO., 2003a, b). Fears and panics are spread when ISIS enter Mosel city and damaged background building. The ISIS entered Mousel University and at Mosul college campus were two sources of cobalt- 60 , where this element radiated Gama ray which is lethally high levels of radiation. This element is contained in heavy shielding of a radiotherapy machine and cobalt-60 usually used to kill cancer cells. In terrorists' hands like ISIS, it is the main ingredient of a "dirty bomb," this weapon can cause a nuclear disaster and a pollution of the city or by Tigris river (Warrick and Morris, 2017).

The aim of this study is field searching of the possibility of using radioactive material by ISIS invasion. The first area under study between Samarra and Himreen hills and the second area was between samara and Mousil where ISIS were presented there and after liberation, the radioactivity was measured along the road in these areas.

Experimental: The first area of study was the road between Samarra city through Allas oil fields in Himreen hills. In June 2017, was the date of measurements, where first dose measured at Samarra fuel filling station, then doses were measured each five miles or more according to the nature of area. The study involved samples of ground and the establishment along the road. The area of study according to satellite map shows in Fig. 1 which is describe the first area of study.

In January 2018, the second regions was accomplished from Samara too toward Mosel reaching Tal Afer city at the Syrian borderlines and it shown in the satellite map in Fig. 2 which is describe the second area of study.

All doses are measured by Giger-Muller instrument count doses in $\mu \mathrm{Sev} /$ year. This detector is supplied by Radiation Alerts company under name "Inspector Giger"manufactured in USA (Fig. 3). 

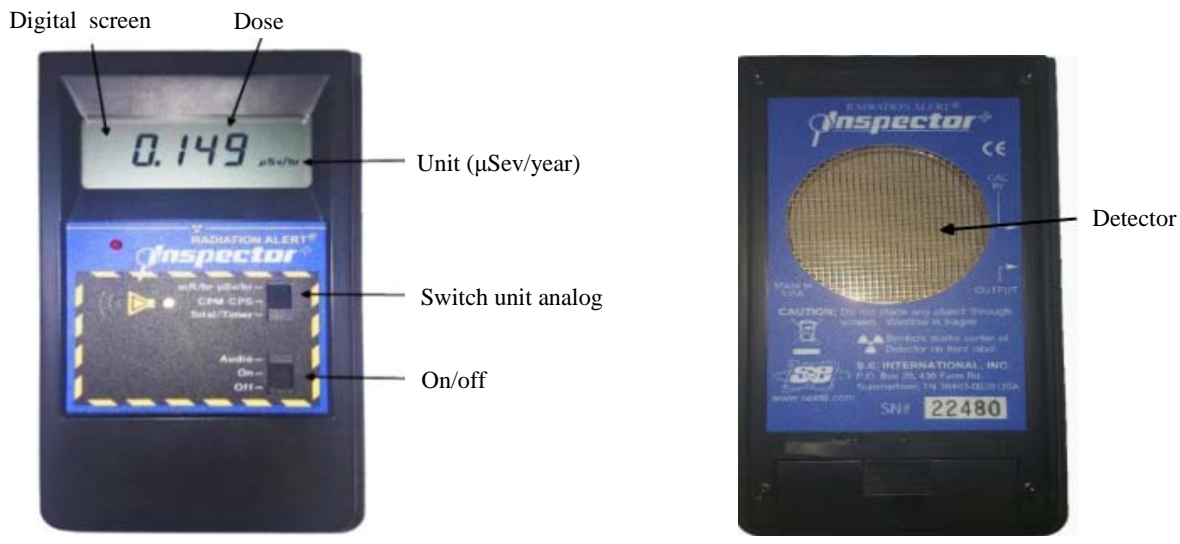

Fig. 3: Geiger dosimeter Instrument (upside left and downside right)

\section{RESULTS AND DISCUSSION}

The study show the field measurement of radioactivity in Iraq along the road between Samarra and Himreen hills and the raod from Samara and Mosel, where these area was under the invasion of ISIS. These first area at length line $51^{\circ} 43^{\prime} 17^{\prime \prime}-59^{\circ} 43^{\prime} 47^{\prime \prime}$ and width line $11^{\circ} 34^{\prime} 15^{\prime \prime}-57^{\circ} 34^{\prime} 23^{\prime \prime}$ and fifteen samples are measured. The possibility was built on the fears of invasion of ISIS to these areas and entered sensitive establishments like universities and hospitals that contained amount of Cobalt-60. This isotope is radiated with Gama ray and might be used for manufacturing of dirty bombs. The does range is between $0.438-1.1388 \mu \mathrm{Sev} / \mathrm{year}$ and these value are comfortable to be normal according to WHO standards and there is no possibility of ISIS are made dirty bombs. According to Table 2 which is showing the doses that measured in the area of study documented by length and width lines and doses are measured in $\mu$ Sev/year, there is no contamination of radioactive material and this area is save and no fears of radiation.

In the second area, the doses were measured along the road from Samara and Mosel cities in the length line $50^{\circ} 34^{\prime} 52^{\prime \prime}-26^{\circ} 42^{\prime} 37^{\prime \prime}$ and width line $11^{\circ} 34^{\prime} 46^{\prime \prime}-22^{\circ} 36^{\prime} 27^{\prime \prime}$. The range of dose was $0.516-1.883 \mu \mathrm{Sev} /$ year, where these values are normal and there is no radioactive pollution. The result of this study in this area are shown in Table 3.

This study was done between June, 2017 and January, 2018 during the supporting campaign of "Alhashd Alshaaby" who fights against ISIS and along the two roads we found the damaged establishments, bridges and main streets by action of bombs. Buildings that are ruined with explosives and which require a large quantity of them. This situation raises the possibility of the use of explosives that may be contain radioactive elements also big bridges are razed and streets with wide hole in ground. Along the roads of this study, the doses were measured close the location $15 \mathrm{~cm}$ in different short
Table 2: Field measurement of radioactivity pollution of fifteen areas between Samarra and Himreen hills

\begin{tabular}{lccc}
\hline Sample & Length line & Width line & Dose $(\mu$ Sev/year $)$ \\
\hline 1 & $51^{\circ} 43^{\prime} 17^{\prime \prime}$ & $11^{\circ} 34^{\prime} 15^{\prime \prime}$ & 0.657 \\
2 & $52^{\circ} 34^{\prime} 06^{\prime \prime}$ & $12^{\circ} 34^{\prime} 12^{\prime \prime}$ & 0.4818 \\
3 & $52^{\circ} 43^{\prime} 43^{\prime \prime}$ & $12^{\circ} 34^{\prime} 30^{\prime \prime}$ & 0.5256 \\
4 & $52^{\circ} 43^{\prime} 57^{\prime \prime}$ & $14^{\circ} 34^{\prime} 32^{\prime \prime}$ & 0.7095 \\
5 & $51^{\circ} 43^{\prime} 7^{\prime \prime}$ & $16^{\circ} 34^{\prime} 42^{\prime \prime}$ & 0.57816 \\
6 & $50^{\circ} 43^{\prime} 22^{\prime \prime}$ & $19^{\circ} 34^{\prime} 09^{\prime \prime}$ & 0.51684 \\
7 & $48^{\circ} 43^{\prime} 50^{\prime \prime}$ & $21^{\circ} 34^{\prime} 26^{\prime \prime}$ & 0.8322 \\
8 & $48^{\circ} 43^{\prime} 03^{\prime \prime}$ & $24^{\circ} 34^{\prime} 20^{\prime \prime}$ & 0.47304 \\
9 & $47^{\circ} 43^{\prime} 45^{\prime \prime}$ & $26^{\circ} 34^{\prime} 53^{\prime \prime}$ & 1.1388 \\
10 & $47^{\circ} 43^{\prime} 29^{\prime \prime}$ & $27^{\circ} 34^{\prime} 45^{\prime \prime}$ & 0.56064 \\
11 & $43^{\circ} 43^{\prime} 34^{\prime \prime}$ & $37^{\circ} 34^{\prime} 60^{\prime \prime}$ & 0.91104 \\
12 & $40^{\circ} 43^{\prime} 30^{\prime \prime}$ & $44^{\circ} 34^{\prime} 44^{\prime \prime}$ & 0.42048 \\
13 & $55^{\circ} 43^{\prime} 18^{\prime \prime}$ & $57^{\circ} 34^{\prime} 04^{\prime \prime}$ & 0.438 \\
14 & $57^{\circ} 43^{\prime} 58^{\prime \prime}$ & $54^{\circ} 34^{\prime} 25^{\prime \prime}$ & 1.1388 \\
15 & $59^{\circ} 43^{\prime} 47^{\prime \prime}$ & $57^{\circ} 34^{\prime} 23^{\prime \prime}$ & 0.5694 \\
\hline
\end{tabular}

Table 3: Field measurement of radioactivity pollution of twenty seven areas between Samarra and Mosel

\begin{tabular}{|c|c|c|c|}
\hline Sample & Length line & Width line & Dose ( $\mu$ Sev/year) \\
\hline 1 & $50^{\circ} 34^{\prime} 52^{\prime \prime}$ & $11^{\circ} 34^{\prime} 46^{\prime \prime}$ & 0.744 \\
\hline 2 & $48^{\circ} 43^{\prime} 09^{\prime \prime}$ & $12^{\circ} 34^{\prime} 37^{\prime \prime}$ & 0.989 \\
\hline 3 & $48^{\circ} 43^{\prime} 38^{\prime \prime}$ & $15^{\circ} 34^{\prime} 04^{\prime \prime}$ & 0.516 \\
\hline 4 & $47^{\circ} 43^{\prime} 33^{\prime \prime}$ & $17^{\circ} 34^{\prime} 38^{\prime \prime}$ & 0.727 \\
\hline 5 & $45^{\circ} 43^{\prime} 52^{\prime \prime}$ & $19^{\circ} 34^{\prime} 55^{\prime \prime}$ & 0.516 \\
\hline 6 & $44^{\circ} 43^{\prime} 33^{\prime \prime}$ & $22^{\circ} 34^{\prime} 16^{\prime \prime}$ & 1.147 \\
\hline 7 & $43^{\circ} 43^{\prime} 57^{\prime \prime}$ & $24^{\circ} 34^{\prime} 52^{\prime \prime}$ & 0.779 \\
\hline 8 & $43^{\circ} 43^{\prime} 25^{\prime \prime}$ & $27^{\circ} 34^{\prime} 26^{\prime \prime}$ & 0.814 \\
\hline 9 & $42^{\circ} 43^{\prime} 24^{\prime \prime}$ & $27^{\circ} 34^{\prime} 59^{\prime \prime}$ & 0.937 \\
\hline 10 & $41^{\circ} 43^{\prime} 28^{\prime \prime}$ & $32^{\circ} 34^{\prime} 31^{\prime \prime}$ & 1.200 \\
\hline 11 & $38^{\circ} 43^{\prime} 30^{\prime \prime}$ & $35^{\circ} 34^{\prime} 02^{\prime \prime}$ & 1.252 \\
\hline 12 & $37^{\circ} 43^{\prime} 40^{\prime \prime}$ & $37^{\circ} 34^{\prime} 19^{\prime \prime}$ & 0.674 \\
\hline 13 & $38^{\circ} 43^{\prime} 11^{\prime \prime}$ & $40^{\circ} 34^{\prime} 07^{\prime \prime}$ & 1.252 \\
\hline 14 & $37^{\circ} 43^{\prime} 04^{\prime \prime}$ & $41^{\circ} 34^{\prime} 40^{\prime \prime}$ & 0.937 \\
\hline 15 & $33^{\circ} 43^{\prime} 55^{\prime \prime}$ & $45^{\circ} 34^{\prime} 12^{\prime \prime}$ & 0.674 \\
\hline 16 & $30^{\circ} 43^{\prime} 42^{\prime \prime}$ & $49^{\circ} 34^{\prime} 30^{\prime \prime}$ & 1.095 \\
\hline 17 & $29^{\circ} 43^{\prime} 02^{\prime \prime}$ & $53^{\circ} 34^{\prime} 33^{\prime \prime}$ & 0.832 \\
\hline 18 & $29^{\circ} 43^{\prime} 08^{\prime \prime}$ & $54^{\circ} 34^{\prime} 27^{\prime \prime}$ & 0.516 \\
\hline 19 & $29^{\circ} 43^{\prime} 38^{\prime \prime}$ & $56^{\circ} 34^{\prime} 06^{\prime \prime}$ & 0.657 \\
\hline 20 & $29^{\circ} 43^{\prime} 40^{\prime \prime}$ & $58^{\circ} 34^{\prime} 13^{\prime \prime}$ & 0.919 \\
\hline 21 & $28^{\circ} 43^{\prime} 25^{\prime \prime}$ & $59^{\circ} 34^{\prime} 46^{\prime \prime}$ & 0.902 \\
\hline 22 & $24^{\circ} 42^{\prime} 43^{\prime \prime}$ & $36^{\circ} 07^{\prime} 09^{\prime \prime}$ & 1.489 \\
\hline 23 & $45^{\circ} 48^{\prime} 07^{\prime \prime}$ & $10^{\circ} 36^{\prime} 56^{\prime \prime}$ & 1.252 \\
\hline 24 & $34^{\circ} 42^{\prime} 58^{\prime \prime}$ & $18^{\circ} 36^{\prime} 35^{\prime \prime}$ & 1.813 \\
\hline 25 & $29^{\circ} 42^{\prime} 06^{\prime \prime}$ & $20^{\circ} 36^{\prime} 20^{\prime \prime}$ & 1.883 \\
\hline 26 & $28^{\circ} 42^{\prime} 33^{\prime \prime}$ & $20^{\circ} 36^{\prime} 50^{\prime \prime}$ & 0.832 \\
\hline 27 & $27^{\circ} 42^{\prime} 54^{\prime \prime}$ & $21^{\circ} 36^{\prime} 32^{\prime \prime}$ & 1.252 \\
\hline 28 & $27^{\circ} 42^{\prime} 28^{\prime \prime}$ & $22^{\circ} 16^{\prime} 15^{\prime \prime}$ & 1.147 \\
\hline 29 & $26^{\circ} 42^{\prime} 37^{\prime \prime}$ & $22^{\circ} 36^{\prime} 27^{\prime \prime}$ & 1.147 \\
\hline
\end{tabular}



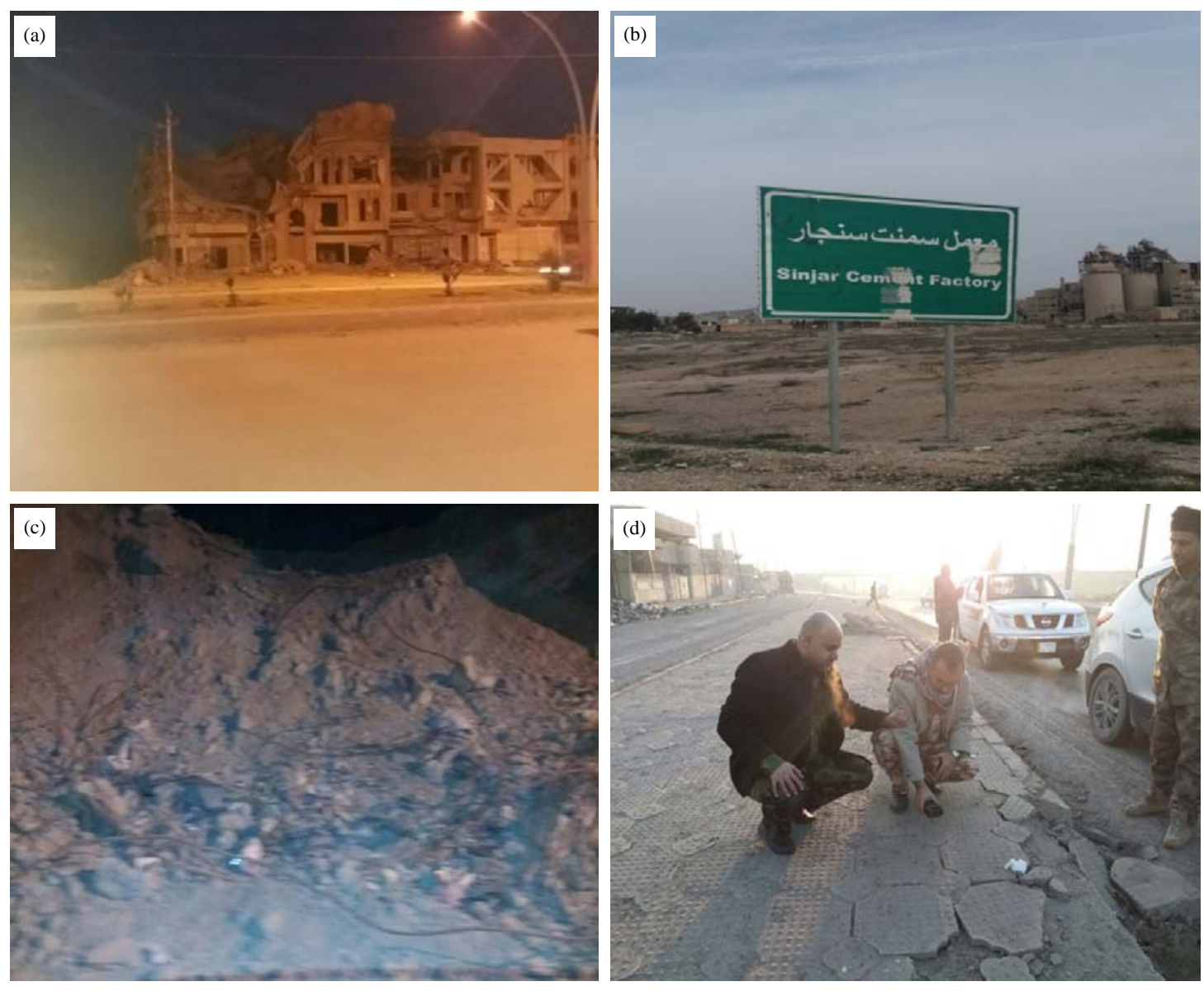

Fig. 4(a-d): Photographic documentation of the damaged regions and dose measurement by the researchers

distance around the location under dose measure. In Fig. 4, a photographic documentation of the damaged regions and dose measurement by the researchers.

\section{CONCLUSION}

This study was measured the radioactive pollution in the liberated lands in Iraq that occupied by ISIS and we found there is no possibility of using dirty bombs. The distance was $500-600 \mathrm{~km}$ and the dose was normal, so no fear about the radioactive pollution and also these regions are clean and no risk on civilians who is living originally in these cities.

\section{REFERENCES}

ATSDR., 2013. Toxicological profile for uranium. Agency for Toxic Substances and Disease Registry, Atlanta, GA., USA. https://www.atsdr.cdc.gov/ toxprofiles/tp150.pdf

Al-Ansari, N., S. Knutsson and K. Almuqdadi, 2014. Engineering solution for radioactive waste in IRAQ. J. Adv. Sci. Eng. Res., 4: 18-36.
Field, R.W., 1999. Radon occurrence and health risk. Ph.D. Thesis, Department of Epidemiology, College of Public Health, University of Iowa Hospitals \& Clinics, Ames, IA., USA.

Grasty, L.R. and J.R. LaMarre, 2004. The annual effective dose from natural sources of ionising radiation in Canada. Radiat. Protect. Dosimetry, 108: 215-226.

Lehto, J. and X. Hou, 2011. Chemistry and Analysis of Radionuclides: Laboratory Techniques and Methodology. John Wiley \& Sons, Hoboken, New Jersey, USA., ISBN: 978-3-527-32658-7, Pages: 397.

Links, J.M., 2006. Radiation, radon, nuclear power and radiation terror. Johns Hopkins Bloomberg School of Public Health, Baltimore, MD., USA. http://ocw. jhsph.edu/courses/EnvironmentalHealth/PDFs/Lect ure16.pdf

Reed, B.C., 2014. A Short History of Nuclear Physics to the Mid-1930s. In: The History and Science of the Manhattan Project, Reed, B.C. (Ed.). Chapter 2, Springer, Heidelberg, Germany, ISBN: 978-3-662-50914-2, pp: 15-70. 
UNSCEAR, 1996. Sources and effects of ionizing radiation. United Nations Scientific Committee on the Effects of Atomic Radiation, New York, USA. https://www.unscear.org/docs/publications/1996/U NSCEAR_1996_Report.pdf

WHO., 2003. Potential impact of conflict on health in Iraq. World Health Organization, Geneva, Switzerland. https://www.who.int/features/ 2003/iraq briefing note/en/index 2 .html

WHO., 2003. WHO/IRAQ area office for the lower South Basrah. Site Report No. 27, July 6, 2003, World Health Organization, Geneva, Switzerland. http:/apps.who.int/disasters/repo/10338.pdf
Wahl, L.E., 2010. Environmental radiation. Fact Sheet, January 2010, Health Physics Society Specialists in Radiation Safety, McLean, VA., USA., pp: 1-6.

Warrick, J. and L. Morris, 2017. How ISIS nearly stumbled on the ingredients for a 'dirty bomb'. The Washington Post, July 22, 2017, Washington, DC., USA.

Zwijnenburg, W., 2013. In a state of uncertainty: Impact and implications of the use of depleted uranium in Iraq. IKV Pax Christi Report, Utrecht, The Netherlands, January 2013, pp: 1-52. 